\title{
THE INFLUENCE OF THE ZOOBIOR REMEDY, USED IN AN IMPLEMENTATION STUDY ON THE HEALTH AND CLINICAL-HEMATOLOGICAL STATUS OF YOUNG HENS IN THE FIRST LAYING PHASE
}

\author{
Vasile Macari, Gheorghe Pistol, Victor Putin, Ana Rotaru, \\ Liliana Rotari, Vasile Oancea
}

State Agrarian University of Moldova, Chişinău, Republic of Moldova e-mail: macvasile@mail.ru

\begin{abstract}
This article presents the scientific results focused on investigating the impact of the ZooBioR remedy, obtained from Spirulina platensis, tested on young hens, in the first technological phase of laying. The research was initiated on young hens, of 24 weeks old, belonging to the "Hy-Line" hybrid, bred in identical conditions of nutrition and maintenance. The hens in the experimental group received daily food supplemented with ZooBioR, in proportion of $10 \mathrm{mg}$ active substance $/ \mathrm{kg}$ feed. During the study the birds were monitored, and periodically were determined body temperature, frequency of respiratory movements. For haematological investigations, from birds was collected blood from the axial veins and, as the case may be, from the jugular veins, in standard model test tubes. It has been established that the ZooBioR remedy is well tolerated by young hens and exhibits anti-stress and adaptive properties. In addition, the tested product has a positive evolution on the hemogram, increases the natural body resistance, inducing at the end of the study a tendency of increase of platelets in blood.
\end{abstract}

\section{Introduction}

It is a well known fact that nowadays we witness a rapid population growth on earth. This phenomenon has positive connotations, but leads to certain problems for the agri-food sector, when it comes to providing earth's population with food, especially food of animal origin. In this regard, Chilimar S. mentions that in the high developed countries, the life standard is quite high, increasing the need of food quantity and quality [2]. According to the same source, in developing countries, as the economic level starts rising, also increases the demand in good quality food.

In this regard, poultry farming, a classic branch of modern animal husbandry, promptly intervenes in ameliorating the problem approached with double commitment: firstly, providing the consumer with meat, and secondly, namely with quality meat, with dietary and therapeutic properties, recommended for several social classes [7]. In the conditions of the Republic of Moldova, namely poultry farming is one of the most stable branches of the agro-industrial complex, which in a relatively short time has rapidly developed, reviving after a transition period the production of meat and eggs, thus contributing essential to ensuring the state food security.

Our research refers to understanding two essential moments: the prohibition of antibiotics and growth promoters in animal husbandry, and the persistent technological stress on poultry farms, etc. In recent years, according to the above-mentioned, an avalanche of research in several countries has started, highlighting the study and implementation in production of new medicinal remedies, giving priority to those of natural origin, especially of plant origin [1, 6 , 7, 15]. 
The paper provides data on the effects of the local remedy ZooBioR, used in an implementation study, on the health and clinical-hematological status of young laying hens, in the first technological phase of laying.

\section{Materials and methods}

The research was carried out in physiological conditions of a poultry factory part of SRL "Technological Acoustics", from Floreni village, Republic of Moldova. The tested remedy was studied on 112 hens, belonging to the Hy-Line hybrid, divided into 2 groups of 56 heads each. The birds were analogous in terms of age, physiological condition, origin, body weight, being housed in the same shelter, with identical environmental conditions and veterinary care.

At the same time, the research objective was focused, both on the new product - ZooBi$\mathrm{oR}$, and on the influence of this remedy on young hens, bred for egg consumption. The tested remedy is of natural origin, containing biologically active compounds derived from Spirulina platensis, including amino acids, immunoactives ones as well, polysaccharides, phospholipids and the trace elements such as zinc and selenium.

This remedy was administered to birds in a ratio of $10 \mathrm{mg}$ active substance $/ \mathrm{kg}$ feed as the optimal dose, which was previously established, during the process of studying four different doses of ZooBioR [6, 8]. The principle of organizing this study is given in table 1 .

Table 1. Scheme of ZooBioR administration to laying hens, $20 \mathrm{mg} / \mathrm{ml}$

\begin{tabular}{|l|c|c|c|c|}
\hline Specification & $\begin{array}{c}\text { No of } \\
\text { hens }\end{array}$ & $\begin{array}{c}\text { Administra- } \\
\text { tion route }\end{array}$ & $\begin{array}{c}\text { Dose, mg active sub- } \\
\text { stance/kg feed }\end{array}$ & $\begin{array}{c}\text { Administration } \\
\text { regimen }\end{array}$ \\
\hline Control & 56 & - & - & daily \\
\hline $\begin{array}{l}\text { Experimen- } \\
\text { tal 1 }\end{array}$ & 56 & $\begin{array}{c}\text { per os } \\
\text { with food }\end{array}$ & 10,0 & \\
\hline
\end{tabular}

In order to assess the health state, at the beginning of the experiment, and later on its interval, the birds were examined, and in 5 hens from each group, have been determined the body temperature and respiratory movements in one minute. To evaluate the impact of the tested product on the hematological status, blood samples were taken in three stages: at the beginning of the experiment, until the administration of the ZooBioR remedy, from 5 random hens; during the study, from 5 birds, each group - about 1 month from the beginning of the study, as well as later, at the end of this experiment, in standard test tubes. The blood samples taken from hens were read using a hematological analyzer: Mindrai BC 5150. The statistical calculation of clinical and hematological indices was made using the parametric criterion t-Student with an error less than $0.05(\mathrm{P}<0.05)$.

\section{Results and discussion}

Based on the examination of birds over a period of 242 days, it has been established that the tested remedy did not cause adverse reactions in the gastrointestinal tract or in the whole body of hens. In addition, according to the research data, the tested product has anti-stress and 
adaptive properties in young laying hens, reflected in body temperature, which is lower by $0.22-0.48^{\circ} \mathrm{C}$ compared to the values of the control group. We also specify that the values of the respiration rate have the same tendency in their dynamics (with 3.6-9.6 movements/min), similar to body temperature, respectively lacking essential changes compared to the values of the control group. These data reflect the harmlessness of ZooBioR, as well as the homogeneity of the birds taken in the study. Similar results have been obtained in the case of testing this remedy on several batches of young laying hens [6], as well as in the case of testing other remedies on animals [12].

The study reveals the strong impact of the tested remedy on the evolution of hematological parameters in young chickens. The dynamics of these indicators is shown in Table 2.

Table 2. Evolution of hematological parameters in laying hens, in the first technological period of laying under the influence of $\mathrm{ZOOBIOR}$ product $(\mathrm{M} \pm \mathbf{m})$

\begin{tabular}{|l|c|c|c|}
\hline \multirow{2}{*}{ Meaning } & \multirow{2}{*}{ Beginning } & \multicolumn{2}{c|}{ Groups of animals } \\
\cline { 3 - 4 } & & CG & EL \\
\hline RBC, $10^{12} / 1$ & $3,16 \pm 0,09$ & $2,92 \pm 0,19$ & $3,01 \pm 0,10$ \\
1 sampling & & $2,28 \pm 0,15$ & $2,41 \pm 0,06$ \\
2 sampling & & & $115,6 \pm 1,20$ \\
\hline HgB, g/1 & $114,40 \pm 1,75$ & $118,4 \pm 0,98$ & $138,0 \pm 2,03^{* * *}$ \\
1 sampling & & $145,8 \pm 2,46^{* * *}$ & \\
2 sampling & $45,04 \pm 0,72$ & $39,40 \pm 1,91^{*}$ & $42,88 \pm 1,10$ \\
\hline HCT,\% & & $34,24 \pm 1,57$ & $36,18 \pm 1,76^{*}$ \\
1 sampling & & $137,84 \pm 1,01$ & $143,02 \pm 2,80$ \\
2 sampling & $139,20 \pm 2,69$ & $150,68 \pm 6,13$ & $141,12 \pm 2,00$ \\
\hline MCV, fl & & & \\
1 sampling & & $35,52 \pm 0,63$ & $37,26 \pm 0,69$ \\
2 sampling & $35,70 \pm 0,69$ & $45,66 \pm 2,60^{* *}$ & $43,32 \pm 1,21^{* *}$ \\
\hline MCH, pg & & & \\
1 sampling & & $285,12 \pm 13,82$ & $271,2 \pm 8,39$ \\
2 sampling & $256,00 \pm 1,56$ & $409,60 \pm 11,63$ & $404,0 \pm 9,62$ \\
\hline MCHC, g/l & & & \\
1 sampling & & & \\
2 sampling & & & \\
\hline
\end{tabular}

Note: $* \mathrm{p}<0,05 ; * * \mathrm{p}<0,01 ; \mathrm{p}<0,001$

The data in table 2 reveal that the parameters of the erythrocyte profile in birds from both groups fall within the physiological intervals, recorded by most bibliographic references. In addition, the number of erythrocytes in blood (RBC) in birds, at the beginning of the study was on average $3.16 \pm 0.09 \times 1012 / 1$, a value which at the first sampling shows a decreasing tendency, the decrease being in the control group $(\mathrm{CG})$ of $7.6 \%$ compared to the base values. At the end of the study, the RBC index shows a clear decreasing tendency, which in the birds from the $\mathrm{CG}$ is $21.9 \%$ compared to the previous research $(\mathrm{p}<0.05)$. The same decreasing tendency of 
erythrocytes values persists in birds in EL, but at the end of the study it is $5.7 \%$ higher than in CG. The value of hemoglobin in the blood of birds from both groups has a positive dynamics during the study, a phenomenon highlighted at the end of the research, when this index in the CG reached the highest level of $145.8 \pm 2.46 \mathrm{~g} / \mathrm{l}$, the difference being significant compared to the 1 st research $(\mathrm{p}<0.001)$. According to the data of the statistical analysis the hemoglobin values increased by $19.4 \%$ in EL, compared to the 1 st research $(\mathrm{p}<0.001)$. At the last stage of the research, the hematological index investigated at EL was 5.4\% lower than the reference values.

According to the data in Table 2, it has been established that the mean erythrocyte volume (MCV) in hens, in the first months of laying, in birds from both groups has practically not changed, while at the end of the study, there is a clear tendency of increase in the CG, of $9.3 \%$. In addition, at this last experimental stage, the value of the investigated parameter in EG proved to be lower by $6.3 \%$ compared to CG, a positive tendency, reported as well by other authors who administered other biologically active remedies to birds [4].

Some authors reported a low level of MCV in the blood of rabbits, a universal biological model, raised in a relatively clean region, compared to the results obtained in an intensely polluted area [13].

The value of mean erythrocyte hemoglobin $(\mathrm{MCH})$ in $\mathrm{CG}$ hens towards the first research term practically did not change, while in birds in EG, on the contrary, it showed a weak growth tendency of $4.4 \%$ compared to the background values, and respectively of $4.9 \%$ compared to $\mathrm{CG}$ values. At the end of the study we can highlight the fact that $\mathrm{MCH}$ has a clear tendency of increase in birds, both from CG and EL, the dynamics being in both cases significant $(\mathrm{p}<0.01)$. However, at this last stage of the research the average value of $\mathrm{MCH}$ in birds in EL is $5.1 \%$ lower compared to the reference values.

The obtained results show that the mean value of MCHC (mean amount of erythrocyte hemoglobin) in birds to the first stage of research has a tendency of $11.4 \%$ in CG birds and of $5.9 \%$ in EG birds, respectively, compared to the reference values. At the end of the study (the 2nd research) the investigated parameter in birds from both groups has a clear upward tendency, of 1.4 times in the CG, and of 1.5 times in the EG, compared to previous values, reported at the 1 st research. In addition, the parameter investigated, at the end of study in the EG, is $1.4 \%$ lower than the CG values.

This fact can be considered positive, because it argues for the correctness of the study, as well as the harmlessness of the remedy tested on hens at the molecular level. In addition, similar tendencies of MCHC decrease in ground-raised broilers, treated with BioR and Catosal remedies, towards the end of the technological process have been found by other authors [11]. The values of the hematological parameters correspond to the values indicated in the literature [5]. When investigating the birds involved in this experiment, a set of data has been obtained with reference to the values of leukocytes and leukocyte components, which are shown in tab. 3. 
Table 3. Dynamics of leukocytes and basic components of the leukocyte formula in young laying hens treated with the product $\mathrm{ZooBioR}(\mathrm{M} \pm \mathrm{m})$

\begin{tabular}{|c|c|c|c|}
\hline \multirow{2}{*}{ Meaning } & \multirow{2}{*}{ Beginning } & \multicolumn{2}{|c|}{ Group of animals } \\
\hline & & CG & EG \\
\hline $\mathrm{WBC}, 10^{9} / 1$ & $12,6 \pm 1,05$ & & \\
\hline 1 sampling & & $12,00 \pm 0,38$ & $11,90 \pm 0,68$ \\
\hline 2 sampling & & $12,06 \pm 0,95$ & $14,12 \pm 1,64$ \\
\hline Lymphocytes, $\%$ & $36,4 \pm 2,23$ & & \\
\hline 1 sampling & & $53,00 \pm 2,35 * * *$ & $47,80 \pm 5,07$ \\
\hline 2 sampling & & $32,8 \pm 3,73 * *$ & $50,6 \pm 7,72$ \\
\hline Granulocytes, $\%$ & $49,8 \pm 2,56$ & & \\
\hline 1 sampling & & $34,60 \pm 3,63^{* *}$ & $43,60 \pm 4,93$ \\
\hline 2 sampling & & $55,4 \pm 3,72 * *$ & $39,0 \pm 7,36$ \\
\hline Monocytes, $\%$ & $10,8 \pm 2,46$ & & \\
\hline 1 sampling & & $12,20 \pm 1,08$ & $8,00 \pm 0,79 *$ \\
\hline 2 sampling & & $10,4 \pm 0,84$ & $9,4 \pm 2,31$ \\
\hline Eosinophils, \% & $0,80 \pm 0,10$ & & \\
\hline 1 sampling & & $0,20 \pm 0,21$ & $0,60 \pm 0,17$ \\
\hline 2 sampling & & $1,40 \pm 0,27$ & $1,20 \pm 0,07$ \\
\hline Trombocytes, $10^{9} / 1$ & $43,6 \pm 7,73$ & & \\
\hline 1 sampling & & $45,20 \pm 6,11$ & $37,40 \pm 3,83$ \\
\hline 2 sampling & & $26,20 \pm 4,02 *$ & $30,40 \pm 0,64$ \\
\hline
\end{tabular}

Note: $* \mathrm{p}<0.05 ; * * \mathrm{p}<0.01 ; \mathrm{p}<0.001$

According to data from table 3, the number of leukocytes in blood at the first stage of research shows a weak decreasing tendency, both in CG of $4.8 \%$ and in EG respectively of 5.6\% compared to the background values, reported at the beginning of the research. Towards the end of the experiment, ZooBioR remedy induced an increase in WBC in blood compared to the CG values, an increase of $17.1 \%$, but without statistical significance. Similar results have been reported by other authors who have administered another biologically active product to adult quails [9].

Particular attention is paid to the investigation of lymphocytes in blood. The value of this parameter in the $\mathrm{CG}$, at the first research, increased significantly compared to the background values, an increase by 1.5 times $(\mathrm{p}<0.001)$. At the same time, there is a similar increase of lymphocytes in the EG (1.3 times), but the difference is not significant compared to the background values. At this first stage of research, the investigated parameter in birds from the EG 
is lower by $9.8 \%$ compared to the CG value. Towards the end of the study, the relative number of lymphocytes in the CG shows a clear tendency of decrease by 1.6 times, compared to the previous values $(\mathrm{p}<0.01)$. In addition, it has been attested a weak growth tendency at $\mathrm{EG}$, by $5.9 \%$ compared to the previous values. At this stage of research, there is a significant increase of blood lymphocytes in hens in EG, which is 1.5 times higher than in CG, the difference being significant.

The value of granulocytes in blood at the beginning of the study is an average of $49.8 \pm$ $2.56 \%$, a parameter that considerably decreases by the first research, especially at CG by 1.4 times $(\mathrm{p}<0.01)$. At the EG this parameter's value is with $26.0 \%$ higher than at the control group, a positive dynamics, as result of using the tested remedy. It reveals the positive dynamics of the population of heterophils/lymphocytes (fewer lymphocytes, and more heterophiles) in birds. This ratio shows an average value of 0.65 in hens in $\mathrm{CG}$, while in EG this parameter is 0.91 units, being 1.4 times higher compared to the CG. Similar results have been reported in other scientific papers as well $[4,10]$. The value of granulocytes in birds from CG towards the end of the study has a clear tendency of an increase by 1.6 times $(p<0.01)$, repeating the late shift of this previous parameter in EL. At this stage, granulocytes value in EL, on the other hand, have a decreasing tendency of $11.8 \%$. At the same time, the investigated parameter in EG is $29.6 \%$ lower than the CG values.

Another studied parameter, blood monocytes, shows an increase tendency in the CG of $13.0 \%$ compared to background values, while in EG, on the contrary, there is a decrease of this parameter, of $25.9 \%$ compared to background values. At the first stage of research, the value of monocytes in EG is considerably lower than in $\mathrm{CG}$ (with $34.4 \%, \mathrm{p}<0.05$ ). At the last term of research, the investigated parameter shows a decreasing tendency $(-14.8 \%$, in $\mathrm{CG})$, while in EG an increase tendency of $17.5 \%$ compared to the previous values. In addition, monocytes in EG are with $9.4 \%$ lower than in CG, a dynamics that can be considered positive. It can be explained by the fact that recent scientific data mention that the decrease of monocytes in the peripheral blood may be a consequence of their migration into tissues, and their transformation and maturation into macrophages [14]. Similar results regarding the decrease of monocytes in blood when administering other bioactive remedies to broilers are also revealed by other authors $[3,7]$.

The analysis of the relative number of eosinophils in blood reveals a similar dynamics, without highlighting some essential divergences in the groups of birds studied.

Table 3 shows that blood platelets value in young hens at the beginning of the research was an average of $43.6 \pm 7.73 \times 109 / 1$, a parameter that, in the 1 st research in CG, increased with $3.7 \%$ if compared with the background values. At the same time, in hens from EL, there is a tendency of decrease of the investigated parameter, of $14.2 \%$ compared to the background values. In addition, at this first stage, the platelet value in EG is lower than in CG, the decrease being of $17.3 \%$. Dynamic monitoring of platelets shows that at the end of the study it had a decreasing tendency in CG, reaching the average value in the CG of $26.20 \pm 4.02 \times 109 / 1$, a decrease of 1.7 times $(p<0,05)$. This decreasing tendency persists in EG birds, but of only 1.2 
times compared to previous values. Still, the investigated parameter in EG is higher than in CG, the increase being of $16.0 \%$.

Our researches have established that supplementing food with ZooBioR product increases the productive potential of hens, a topic that will be addressed in a separate study.

\section{Conclusions}

1. The research was carried out on young hens, in the first technological phase of laying eggs, raised on a poultry farm, in identical nutritional and maintenance conditions, and the ZooBioR product was well tolerated by birds and did not cause any adverse reactions.

2 . In the experimental group, treated with ZooBioR, body temperature and respiratory movements decreased which proves the adaptive and anti-stress action of the tested product.

3. The haematological examination in laying hens highlights the positive dynamics of the haemogram, results that prove both the beneficial effect of ZooBioR, and its harmlessness at cellular level.

4. It has been established that the medication of hens with the remedy ZooBioR increases the natural body resistance both at general and local levels, inducing at the end of the study a tendency of blood platelets increase.

5. The product ZooBioR, a natural, autochthonus remedy determines hens ' health improvement in the first technological phase of laying eggs, thus stimulating their productive potential.

\section{Bibliography}

1. Becze, A., Cepoi, L., Simedru, D., Rudi, L., Chiriac, T., Rudic, V. Study regarding the influence of the salinity stress on the antioxidant capacity of Arthrospira platensis. Agriculture, Science And Practice Journal. 2017, V.103 (3-4), p.12-16.

2. Chilimar S. Situaţia şi perspectivele sectorului zootehnic în Republica Moldova. În: Lucrări ştiinţifice ale UASM, Zootehnie şi Biotehnologii, 2010, vol. 26, p. 25-33.

3. Ciulan V. ş.a. Efectul curativ al vitaminei E şi al Biselenitului de sodiu în hipovitaminoza E şi hiposelenoza puilor broiler. Lucrări ştiinţifice. USAMVBT. Timişoara. 2000, vol. XXXIII: Medicină veterinară, p. 355-358.

4. Curcă, D., Răduţă, A., Pantă, L., Unele observaţii privind efectele suplimentării hranei cu seleniu şi respectiv L-carnitină la puicuţe, Lucrări ştiinţifice ale Universităţii Agrare de Stat din Moldova, Medicină Veterinară, 2014, vol. 40. p. 242-247.

5. Glomski C, A., Pica A. The Avian Erythrocyte:its Phylogenetic Odyssey, Jersey: Science Publishers, 2011, $640 \mathrm{p}$.

6. Macari V., Pistol GH., Putin V. Efectele produsului ZooBioR- remediu autohton utilizat în difrite doze - asupra sănătăţii şi productivităţii găinilor ouătoare în prima fază de ouat. In: Ştiinţă, educaţie, cultură: materialele conf. şt.-practice intern., 12 feb. 2021, Universitatea de Stat din Comrat, 2021, vol. I, p. 187-191.

7. Macari V., Putin V., Rudic V., Macari A., Bălănescu S., Enciu V. Recomandări. Procedeu de ameliorare a sănătăţii şi stimulare a productivităţii la puii de carne. Chişinău: UASM. „Print-Caro", 2014, 35 p.

8. Macari V., Rudic V., Gudumac V. etc. Effects of food supplemented with ZooBioR product in young chickens on the functional state of the liver. In: Lucrări ştiinţifice, USAMV „Ion Ionescu 
de la Brad”. Iaşi, 2020, vol. 63 Medicină Veterinară, Partea. 1, p. 25-32.

9. Pavlicenco N., Efectele remediului BioR asupra indicilor fiziologo-metabolici şi bioproductivi la prepeliţă: autoref. tz. doct. în ştiinţe biologie. Chişinău, 2019. 29 p.

10. Putin, V., Macari, V., Rotaru, A. Noi oportunităţi în ameliorarea sănătăţii şi stimularea productivităţii la puii de carne. Chişinău: «Print-Caro», 2020. 127 p.

11. Rotaru A. Impactul remediului BioR asupra statusului pro-antioxidant la puii broiler şi prepeliţe. Autoref. tezei. dr. în şt. medical-veterinare. Chişinău, 2016. 31 p.

12. Воробьев, А. В., Датченко, О. О. Влияние экспериментальных биопрепаратов на общее состояние, мясную продуктивность и качество мяса кроликов. Достижения современной науки и практики в области охраны здоровья животных и человека: материалы региональной научно-практической межвузовской конференции, Самара, 2011, с, 49-54.

13. Кашапова Р. А. Гематологические показатели у кроликов, содержащихся в различных условиях загрязнения окружающей среды: автореф, дис, канд, биол, наук, Казань, 2007, $19 \mathrm{c}$.

14. Кочиш И. И. и др. Воздействие солей лития на механизмы адаптивного иммунитета цыплят-бройлеров при вакцинации. VII-й Междунар. вет. Конгресс по птицеводству, Москва, 12-15 апр. 2011, с. 169-173.

15. Краснобаев Ю. В. Астравит-поддержка иммунитета в критические периоды. Птицеводство. 2020, № 04, с. 21-24. 